\title{
Construction technology transfer in Shanghai in the nineteenth to twentieth centuries
}

\author{
Jingxian Ye \\ Shanghai, China \\ Corentin Fivet \\ École Polytechnique Fédérale de Lausanne, Lausanne, Switzerland
}

\begin{abstract}
Shanghai, in the early twentieth century, was a big construction site and attractive experimental field for Western designers. Because of its significant location and international role, the construction activities contributed to some landmarks of the world architecture history. In addition to famous architects, local builders played a crucial role in the realization of these edifices. Introduction and application of new technologies, digestion and diffusion of new knowledge, transportation and production of new materials, the magnification of pre-existing local concerns while dealing with the geological problem, as well as the training of the workers was already solved by the natives at this time. Based on a fresh study of the documents in the Historical Archives of Shanghai Library and in the Shanghai Local Chronicles, this particular context is here used as a case-study that aims at providing new insights on the shifts from traditional construction practices to industrialized dynamics. This paper reveals that the construction technology transfer that happened between Europe and East Asia in Shanghai in the nineteenth to twentieth centuries in a sense was a process of local desire to extract knowledge and technologies from numerous overseas sources for the construction of "Modern Shanghai".
\end{abstract}

KEYWORDS: 19th-20th centuries, Shanghai, Modern Architecture, Construction Technology Transfer, Adoption and Improvement

\section{THE NATIVE BUILDERS OF THE "ORIENTAL PARIS"}

Located in the Yangtze River Delta, Shanghai sits on the south edge of the estuary of the Yangtze in the middle portion of the East China Coast. Its predominant geographical position favoured transport and trade. After the establishment of the Shanghai Customs in 1685, Shanghai became the largest port for marine trade in the Far East. Shanghai's first building boom occurred in the 1920s and 1930s, during the city's heyday as a multinational centre for business and finance. The city's international concessions permitted foreign investment, and with it came architectural styles from the West. Shanghai has been hailed as the "Oriental Paris" for all those reasons.

One of the most famous edifices is Park Hotel (Fig. 1). It was the tallest building in Asia from its completion in 1934 to 1958 (Jiang 2008). With 22 stories above ground it is $83.8 \mathrm{~m}$ high. The building was designed by Hungarian-Slovakian architect László Hudec (Poncellini 2013), and built by Chinese Voh Kee Construction Company. Its piling project was

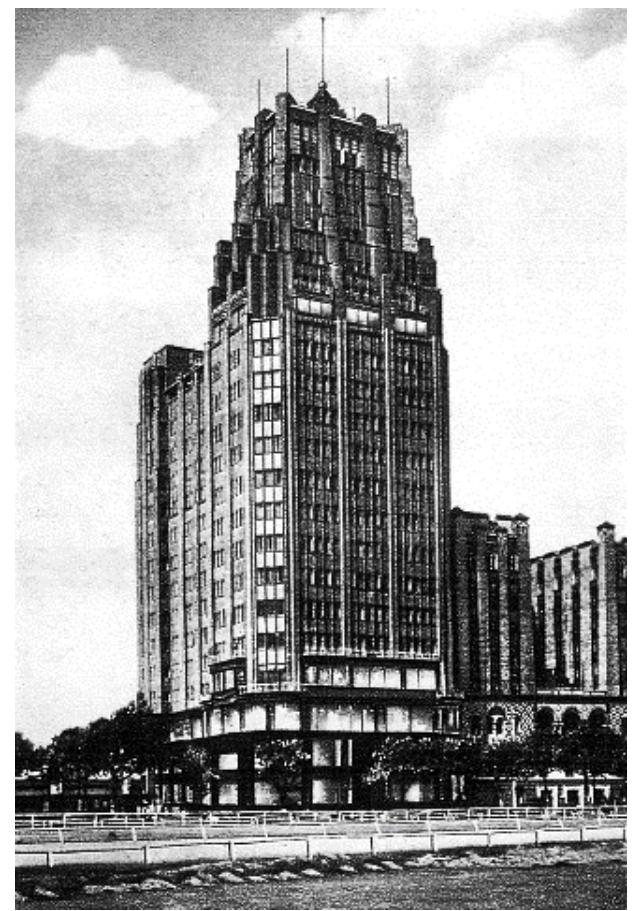

Figure 1. Outside view of Park Hotel, Shanghai, László Hudec, 1934, provided by Shanghai Pictorial. 
conducted by Danish Aage Corrit Company, operated by Chinese Yah Sing Kee Construction Company.

Park Hotel was considered as the most advanced and modern building in the Far East for the following reasons (Poncellini 2013):

(1) In China, it was the first time that statistical calculation of wind stress was applied for high-rise steel construction.

(2) The Steel Sheet Piling was imported from Germany to solve the problem of the soft soils in Shanghai.

(3) The newly developed steel-framed structure and steel material "Union Baustahl 52" were adopted. It was a considerably light copper-chromium-containing alloy steel, patented in 1928, manufactured by Vereinigte Stahlwerke AG in Dortmund Germany, with excellent properties of anti-corrosion and tension. As a result, the weight of the entire building was reduced by $33 \%$, and the construction cost decreased greatly accordingly. Despite its first application in Asia, Voh Kee Co. accomplished the construction perfectly without the guidance of German experts.

(4) Besides three standard elevators for the guests, another service elevator was installed, which could carry the cars to the parking on the second floor.

(5) Each room was well equipped with air conditioning and heating system.

(6) It was the first time that an automatic sprinkler system was adopted for fire control in China.

(7) There were two sets of water supply systems. One was a regular urban tap water supply, and another was a standby system, equipped with the artesian well. The groundwater could be pumped through compressed air and sent to the roof water tank after gravel filtration.

Table 1. Buildings with reinforced concrete structure in Shanghai from 1908 to 1937 (Haiqing 2004).

\begin{tabular}{|c|c|c|c|}
\hline Projects & Year & Story & Builder \\
\hline $\begin{array}{c}\text { 上海德律风公司 } \\
\text { De lv feng Building }\end{array}$ & 1908 & 6 & $\begin{array}{l}\text { 姚新记 (native) } \\
\text { Yah Sing Kee Co. }\end{array}$ \\
\hline $\begin{array}{c}\text { 友邦大厦 } \\
\text { North China Daily } \\
\text { News Building }\end{array}$ & 1924 & 9 & $\begin{array}{c}\text { 茂生洋行(American) } \\
\text { American Trading Co. } \\
\text { of The Far East }\end{array}$ \\
\hline $\begin{array}{c}\text { 上海邮政总局 } \\
\text { Shanghai Headpost }\end{array}$ & 1924 & 8 & $\begin{array}{c}\text { 余洪记 (native) } \\
\text { Ah Hong Kee }\end{array}$ \\
\hline $\begin{array}{c}\text { 新亚酒楼 } \\
\text { New Asia Hotel }\end{array}$ & 1934 & 9 & $\begin{array}{c}\text { 陆顺记 (native) } \\
\text { Lu Shun Kee }\end{array}$ \\
\hline $\begin{array}{c}\text { 德邻公寓 } \\
\text { Derling Apartments }\end{array}$ & 1934 & 7 & $\begin{array}{l}\text { 怡昌泰 (native) } \\
\text { Yi Chang Tai Co. }\end{array}$ \\
\hline $\begin{array}{c}\text { 毕卡第公寓 } \\
\text { Picardie Apartments } \\
\end{array}$ & 1935 & 15 & $\begin{array}{c}\text { 利源公司 (native) } \\
\text { Li Yuan Co. }\end{array}$ \\
\hline $\begin{array}{c}\text { 道斐南公寓 } \\
\text { Dauphine Apartments }\end{array}$ & 1935 & 9 & $\begin{array}{l}\text { 安记 (native) } \\
\text { An Kee Co. }\end{array}$ \\
\hline $\begin{array}{c}\text { 峻岭寄庐 } \\
\text { The Grosvenor House }\end{array}$ & 1935 & 18 & $\begin{array}{l}\text { 新荪记 (native) } \\
\text { Xin Sun Kee Co. }\end{array}$ \\
\hline $\begin{array}{c}\text { 大新公司 } \\
\text { The Sun Department }\end{array}$ & 1936 & 10 & $\begin{array}{l}\text { 馥记 (native) } \\
\text { Voh Kee Co. }\end{array}$ \\
\hline $\begin{array}{c}\text { 迦陵大楼 } \\
\text { Liza Hardoon Bui }\end{array}$ & 1937 & 14 & $\begin{array}{c}\text { 陶桂记 (native) } \\
\text { Dao Kwei Kee Co. }\end{array}$ \\
\hline
\end{tabular}

After completion, the building was widely reported in European architectural journals, such as the French L'Architecture d'Aujourd'hui (Poncellini 2013), and the German Deutsche Bergwek-Zeitung in April 1940 (Poncellini 2013). The realization of this "skyscraper" marked not only the high level of architectural design but also the excellent ability of construction at that time. Moreover, according to statistics in Shanghai Local Chronicles, all the construction projects of 31 high-rise buildings with more than ten stories in Shanghai in the 1930s were undertaken by native construction companies. Information on some significant public buildings and apartments built in 1908-37 are listed in Tables 1 and 2.

Still, for thousands of years in Chinese history, no concept of engineer or architect did exist. Practically, based on the experience of the carpenters and the requirements of the owners, the traditional Chinese buildings were constructed just after several rough sketches. Given such a background, how could these Chinese builders master the most advanced construction technologies and occupy a significant share of the market in the construction industry in Shanghai?

\section{FROM TRADITIONAL CONSTRUCTION TO INDUSTRIALIZED DYNAMICS}

\subsection{Construction before 1845}

Before 1845, Western countries had come to Shanghai and engaged in trade and missionary work for about 300 years. During this period, some Western churches were built up. They mainly mix western masonry with Chinese timber framed systems, with western decoration. A representative example is the Qiujiawan Jesus Church in Shanghai Songjiang, which was built in 1658 and rebuilt in 1872 . The inside wooden frames were constructed in the form of masonry arches from European churches.

Table 2. Buildings with steel-framed structure in Shanghai from 1917 to 1937 (Haiqing 2004).

\begin{tabular}{c|c|c|c} 
Projects & Year & Story & Builder \\
\hline $\begin{array}{c}\text { 有利大厦 } \\
\text { No. 4 of the Bund }\end{array}$ & 1917 & 7 & $\begin{array}{c}\text { 裕昌泰 (native) } \\
\text { Yu Chang Tai }\end{array}$ \\
\hline $\begin{array}{c}\text { 汇丰银行 } \\
\text { The Building of HSBC }\end{array}$ & 1923 & 6 & $\begin{array}{c}\text { 德罗公司(English) } \\
\text { Trollope \& Coils }\end{array}$ \\
\hline $\begin{array}{c}\text { 江海关 (第三期) } \\
\text { Shanghai Customs III }\end{array}$ & 1927 & 8 & $\begin{array}{c}\text { 薪仁记 (native) } \\
\text { Xin Ren Kee Co. }\end{array}$ \\
\hline $\begin{array}{c}\text { 华㭠公寓 } \\
\text { Jin Jiang Hotel }\end{array}$ & 1929 & 14 & $\begin{array}{c}\text { 英商华㻑公司 } \\
\text { (English) }\end{array}$ \\
\hline $\begin{array}{c}\text { 沙逊大厦 } \\
\text { Sassoon House }\end{array}$ & 1929 & 13 & $\begin{array}{c}\text { 薪仁记 (native) } \\
\text { Xin Ren Kee Co. }\end{array}$ \\
\hline $\begin{array}{c}\text { 四行储会大厦 } \\
\text { Park Hotel }\end{array}$ & 1934 & 22 & $\begin{array}{c}\text { 馥记 (native) } \\
\text { Voh Kee Co. }\end{array}$ \\
\hline $\begin{array}{c}\text { 百老汇大厦 } \\
\text { Broadway Mansions }\end{array}$ & 1934 & 21 & $\begin{array}{c}\text { 薪仁记 (native) } \\
\text { Xin Ren Kee Co. }\end{array}$ \\
\hline $\begin{array}{c}\text { 中国银行 } \\
\text { Bank of China }\end{array}$ & 1937 & 17 & $\begin{array}{c}\text { 陶桂记 (native) } \\
\text { Dao Kwei Kee Co. }\end{array}$
\end{tabular}


At that time, the construction of traditional wooden buildings was still the mainstream. Workers and craftsmen were distributed in the countryside. They formed a team and participated in construction in the slack season. Upon completion, the team dissolved automatically.

\subsection{5-80: setup of the concession}

Modern industrial buildings were introduced after the opening of the commercial port and the definition of the concessions in 1845, a great deal trade. It was another opportunity for the western construction technologies to be imported into China. The main performances were as follows: new materials and structural typologies were applied, such as steel, concrete and truss structure; and a trend of multi-storied and largespanned construction grew up.

At the same time, the administrative environment for construction greatly changed as well. The Municipal Council formulated The Building Regulations ( 《建筑章程》), which prescribed the heights, boundary lines and firewalls of the buildings, the distance between them, the drainage system and hygiene requirements.

In addition, a group of western architects came and designed a large number of western-style buildings, including municipal, public and private projects. Nevertheless, the life of these western-style houses was very short. The British Consulate, built in 1843, had to be pushed over and rebuilt after three years, because of serious structural movements and wall cracking (Xiaohua 2011). The French Consulate, built in 1867 near the Bund, was demolished in 1884, once it was realised that the foundation was damaged by humidity (Xiaohua 2011).

Why did many construction problems emerge at that time? On the one hand, the climate and geological conditions were quite different from those in the west, particularly the soft soil in Shanghai. On the other hand, the western masonry system was much heavier than the Chinese wooden framed buildings.

Obviously, these new challenges also put forward new requirements on other relevant disciplinary fields as well, such as construction, measuring and mapping, geologic and hydrogeological surveying, and the manufacture of new building materials. It motivated Chinese architecture to enter into a modern time.

\subsection{0-1920: from foreign to native builders}

The earliest engineers and architects who were trained abroad did not return until the 1910s to take part in the practice. There is no doubt that these onsite builders and workers were initially involved in applying the Western architectural system. They faced a collision of cultures and at the same time took the opportunity for direct exchange. Under the context of great reform, the native workers showed a strong capacity of digestion and application.

Piling was particularly critical in the construction in Shanghai. Because Shanghai was created over an accumulation of alluvium and silt in the salt marshes of the Huangpu River, the soil was soft and unfavourable for western masonry construction. Consequently, piling was the most important item to be considered when judging a construction company (Wenda 1997).

In 1880, a local bricklayer YANG Sisheng registered the first native construction company, Yang Rui Tai Co., in the concession. The bricklayer was previously a full-time craftsman employed by Palmer \& Turner Group. In 1891, in the construction of the building of Shanghai Customs II, the Italian builder gave up the piling task because of the soft soils and the rise of underground water table. YANG, serving as a subcontractor for a long time, seized the opportunity. He studied the reasons for the designer's choice of yellow fir pile at first, and then experimented repeatedly. Finally, he not only accomplished the piling work but also took over the entire construction project (Xiaohua 2011). When the building was finished, YANG sprung into fame in Shanghai. From then on, more and more significant projects were contracted directly by native companies. Unfortunately, the details of YANG's construction could not be found in the published official documents.

\subsection{0-37: prosper period of the native construction industry}

From 1895 to 1920 , some competitive foreign enterprises in the construction industry in Shanghai, such as English Trollope \& Coils Ltd. and French Shanghai Construction Company, introduced the market. They contracted most of the significant projects in the concession, like the building of HSBC, Macquarie Bank and the Catholic Church in Xujiahui (Xiaohua 2011).

From the 1920 s to 1930 s, with the booming of the real estate industry, the construction industry entered into a period of prosperity. In particular, the native construction companies increased dramatically. According to the records in the Shanghai Local Chronicles, there existed more than 50 large-scale construction companies in 1916, in which foreign ones accounted for 22, and native ones accounted for 31 . In 1930, more than 100 native construction companies were registered, while foreign ones remained at 20 . By the end of 1934, the total amount of construction companies and manufactures of building material was up to 2623 (Kun 2011).

In order to keep a healthy and orderly environment for the construction industry in such rapid development, several societies were organized spontaneously 
by professionals and builders. In the field of architectural design, "The Society of Chinese Architects" was established in 1927; the journal "The Chinese Architect" was first published in November 1932. In the field of construction industry, "The Shanghai Builders' Association" was set up in 1930 (Fig. 2); the journal "The Builder" (Fig. 3 Left) was founded in November 1932.

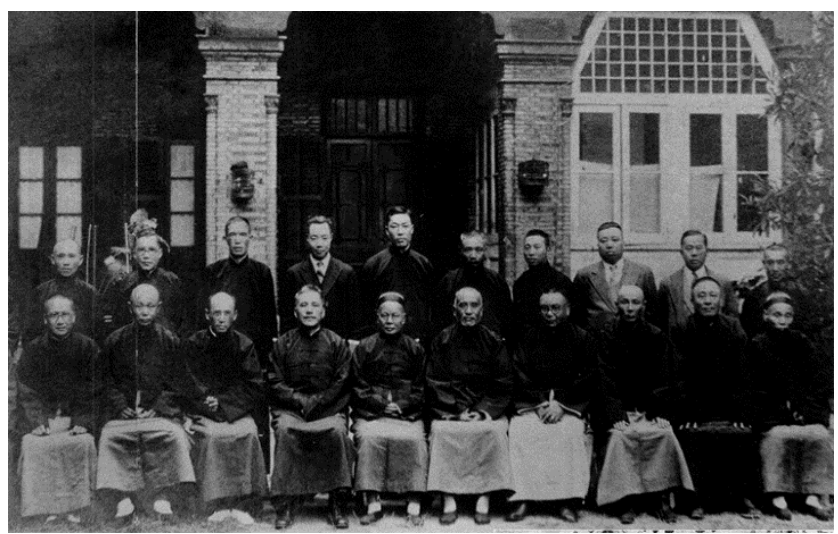

Figure 2. The Shanghai Builders' Association, 1930, provided by Shanghai Pictorial.

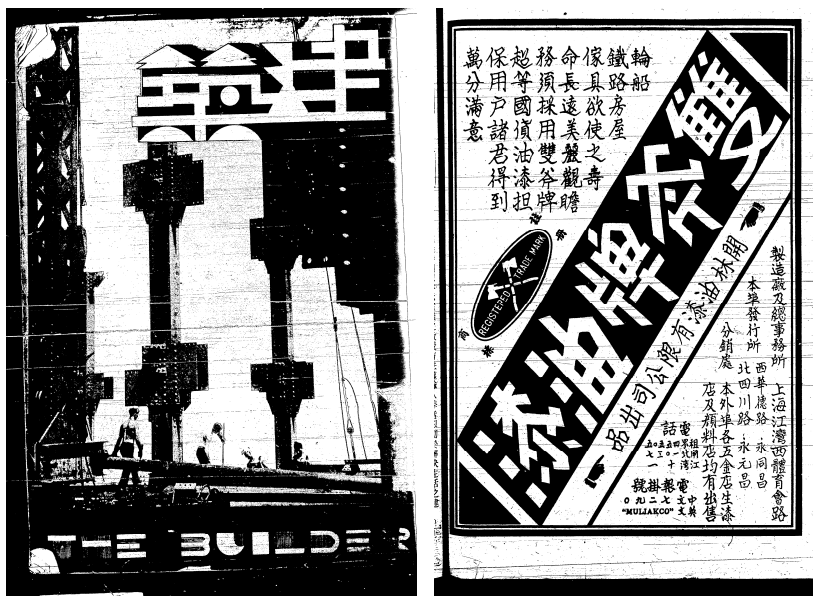

Figure 3. Left: The cover of the first issue, The Builder, 1932.11, provided by Shanghai Library.

Right: The paint advertisement of the first issue, The Builder, 1932.11, provided by Shanghai Library.
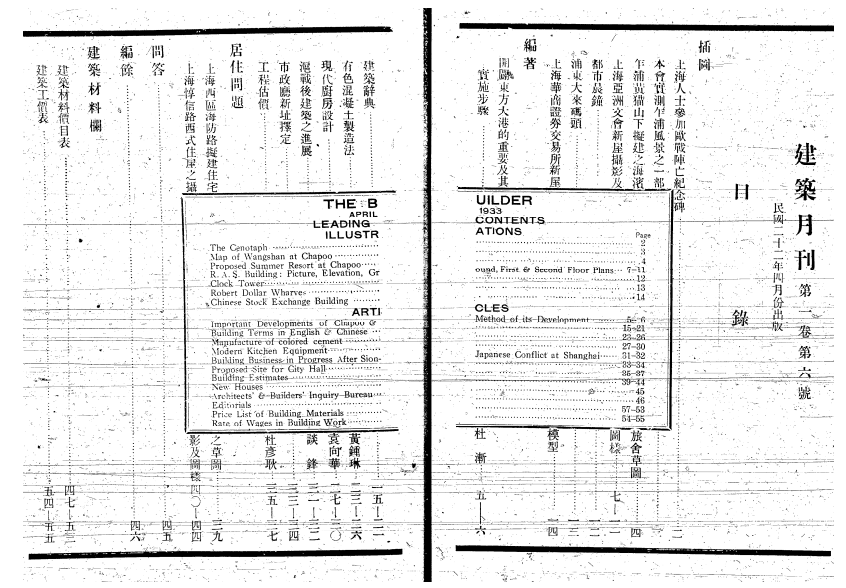

Figure 4. The contents in Chinese and English, The Builder, 1933.04, provided by Shanghai Library.
"The Shanghai Builders' Association", as "Association" for short in this paper, was an academic group. It was initiated in 1930 by the builders TAO Guilin (founder of Dao Kwei Kee Co.), DU Yangeng, TANG Jingxian, etc., aiming to jointly associate builders, architects, engineers, supervisors and manufacturers. On February 28 1931, it was officially established with more than 100 members. The purposes of the association were to develop and improve new technologies, to promote domestic building materials and to provide knowledge for builders and workers.

By 1937, the following contributions have been made by the Association: 1) published an academic journal "The Builder"; 2) promoted the government to unify the measurement in China; 3) established "Zhengji Construction Tutorial School"; 4) held the first China Architectural Exhibition; 5) promoted the exchange with the professionals and other associations; 6) planned to establish Bank of Construction, although unrealized.

\section{3 "THE BUILDER"}

The Builder was published by the Association from November 1932 to April 1937, with a total of 46 issues. The preface, carried out in the first issue, addressed its prospects and goals: 1) to improve traditional architecture with a scientific approach; 2) to improve native manufactured materials with scientific technologies; 3 ) to provide the latest information on architecture and construction in the world; 4) to encourage native improvement and inventions on technology and equipment.

In addition to The Builder, The Journal of Society for The Study of Chinese Architecture and The Chinese Architect were two other influential journals in this field at that time in China. The former introduced the ancient Chinese architecture and culture; the latter focused on the practice of native architects, while The Builder paid more attention to construction and practical application. It valued the mastery of science and technology, instead of the analogue of the western architectural form. The shortcoming of underestimating engineering and technology in traditional Chinese mind-set was particularly pointed out at the beginning of the preface. Although the construction in Shanghai dramatically developed, most of the realisations depended on imported technologies and materials. Accordingly, this journal was created to inspire Chinese to form a scientific approach in academy and practice.

The Builder was composed of four parts: Illustration, Articles, Communication, and Advertisements. 1) "Illustration", in the form of image display, introduced the latest completed-, under construction-, and proposed projects both in the West and in China; 2) "Articles" discussed architecture and construction concretely from the view of design, technology, architectural history, aesthetics, structure, materials, 
etc.; 3) "Communication" mainly posted the official announcements of the Association. The exchange and activities with the professionals, readers, and other associations were intensively introduced as well; 4) In "Advertisements" (Fig. 3 Right), native builders, domestic suppliers of building materials and equipment, and design companies thronged to gain the opportunity to propagate. The price list of the building materials was monthly offered in this column.

Based on original issues of The Builder in the Historical Archive of Shanghai Library, these 46 issues are here introduced from the following three angles: the chief editor, western reports and native reports. The main list of content is translated and attached in the Appendix of this paper.

\subsection{The chief editor: DU Yangeng}

Mr DU Yangeng, one of the initiators of the association, served as chief editor of the journal until its suspension. He was born in 1896 in Shanghai. His father was owner of a native construction company. At the age of 30 , he undertook the construction of a sevenstory office tower on his own, which was already very tall in Shanghai at that time. In his spare times, he studied construction technologies and English assiduously. After the foundation of the journal, most of his time was devoted to editing and writing work. Under DU Yangeng or the pseudonym of DU Jian, he posted his writings, accounting for more than 15 percent of all the articles in 46 issues. The following columns are created and accomplished by him:

[Building terms in English and Chinese] The building terms across China were not unified at that time, which in the inter-translation with English were always confusing. To facilitate the academic discussion and promote the development of the construction and architecture, as well as inspired from the EnglishJapanese Architectural Dictionary, Mr DU opened the special column of Building terms in English and Chinese (Fig. 5 Left) from January 1933 to September 1934. He drafted every manuscript. Extensive discussion was received following the interest of the readers. This column was the original version for $E n-C h$, Ch-En Architectural Construction Dictionary, the earliest bilingual dictionary of architecture and construction in China. It was officially published in June 1936.

[Western Architectural History] From July 1935 to April 1937, The Builder serialized DU's translation of Western Architectural History, including Egyptian, Central Asian, Persian, Greek, Roman, early Christian, Muslim, France Roman, German, and Roman architecture. They were described from the perspective of geography, history, ethnic, architectural style and typical examples. Unfortunately, the original book could not be traced in available libraries.
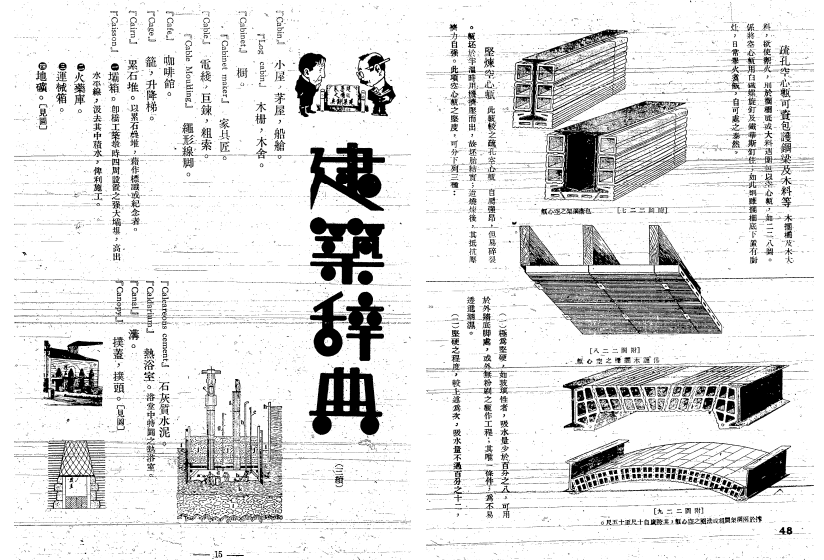

Figure 5. Left: Building terms in English and Chinese, The Builder, 1933.04, provided by Shanghai Library.

Right: Chapter II of Masonry, The Builder, 1936.01, provided by Shanghai Library

[Construction] From July 1935 to April 1937, DU dedicated great efforts on the column of Construction. It was divided into five chapters: Masonry with bricks, Masonry with stone, Basement, Carpenter, and Slab. Among which masonry (Fig. 5 Right) has been extremely detailed discussed, from raw materials to manufacture, from tools to machinery and from masonry wall to mortar joint. This section was well received by the readers because numerous masonry constructions were built in this period. Up to now, it is one of the most comprehensive explanation of western masonry technology in Chinese architectural literature. In the chapter on Basement, the construction of traditional Chinese stone base was also addressed.

[Building Estimates] From the first issue to April 1935, DU elaborately compiled Building Estimates for 12 chapters, including earthwork, cement and concrete work, brick-walls, stone-walls, carpenter, steelframed windows, metal, painting, and piping. Based on his practical experience and interviews, this column provided some new approaches for the cost-estimation of materials and workloads. See for instance, the article "Formulas of Mortar" published in June 1933.

Other topics were written by DU as well, such as "The Suggestions of Reform in the Chinese Construction Industry", the architecture in Japan, "Inquiry Bureau" with the readers, etc. In 1936, DU Yangeng contacted the Society of Chinese Architects and the Society for the Study of Chinese Architecture to organize the first China Architectural Exhibition. It was successfully held in July 1936 in Shanghai.

As stated by Shanghai Local Chronicles, Mr DU Yangeng is the sole person in Chinese history who introduced the western architecture and culture in such a comprehensive way, from building-styles to technologies, from materials to equipment, and from history to practical projects. He has made a significant contribution to the Chinese modern architecture and construction. 


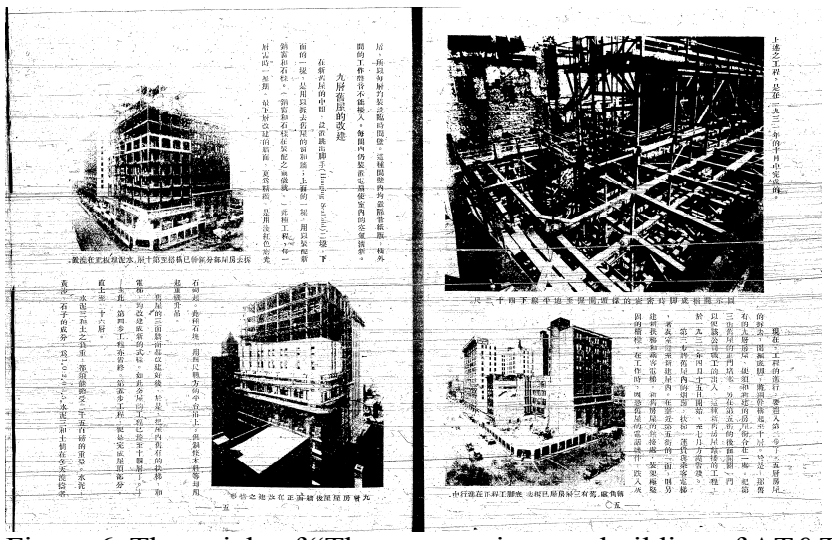

Figure 6. The article of "The twenty-six story building of AT\&T in America", The Builder, 1932.12, provided by Shanghai Library.

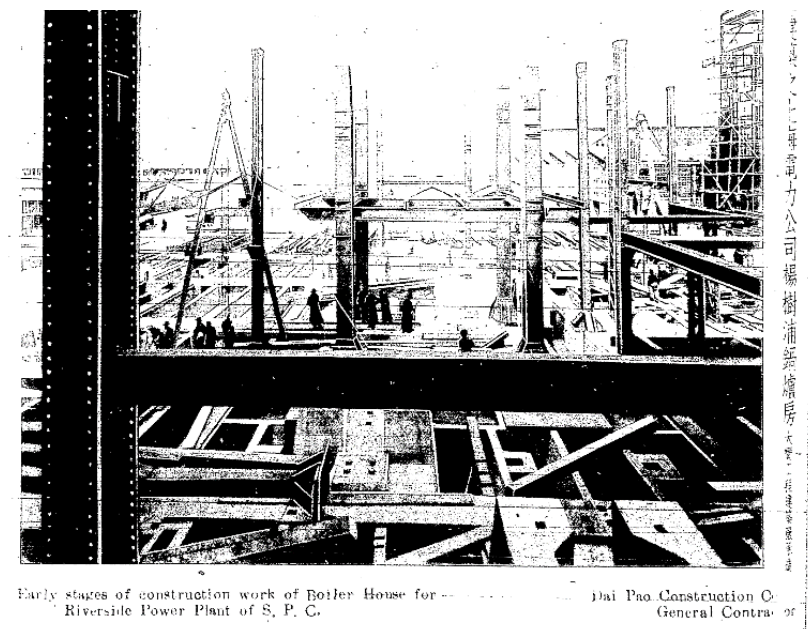

Figure 7. Construction work of Boiler House for Riverside Power Plant of S.P.C., The Builder, 1933.05, provided by Shanghai Library.

\subsection{Dissemination of western construction}

Reporting on western construction and technology was the major task of this journal. Most of the articles were provided by professionals returning from abroad. The main contents could be catalogued into the following three sections:

[Latest western projects] In addition to the finished works, The Builder paid great attention to the construction process and offered detailed interpretation on the applied technologies. In the article of "The twenty-six story building of AT\&T in America" (Fig. 6 ), issued in December 1932, the construction of foundation, the proportion of cement and sands, the method of pouring concrete, etc. were introduced. Further, there existed many reports on European bridges and tunnels as well, which was in line with China's desire to build infrastructures.

[Latest western technologies, equipment, and materials] In this section, the concrete pouring technology was always an important topic. Some newly developed steel with specific index of properties were also introduced. Because of the great success of Park Hotel, the applied Steel "Union Baustahl 52" was introduced in focus in August 1936. In addition, civil engineering was intensively discussed with substantial emphasis. From January 1934 to January 1936, the well-known structural engineer LIN Tung-yen, contributed to more than ten articles, such as "Hardy Cross Methods of Moment Distribution" and "Calculating the $C, K, F$ Properties of a Member”.

[Latest reports of exhibition, conference, education, and association in the west] The journal also presented the western latest exhibition and congress in time. The 50th Anniversary of the Illinois Institute of Engineers was held from January 31 to February 2 in 1935 , the news and reports were published in the issue of February 1935 immediately. In February 1937, the preview report about the "1939 Architecture Expo in New York" was carried out. The education for architects in different universities in the USA and professional associations like RIBA were compressively introduced as well.

The journal has tried to expand its international influence. The contents were monthly translated from Chinese into English (Fig. 4) from April 1933 to December 1934. In November 1933, the American Institute of Architects sent an invitation letter to the Association: "We are very pleased to receive the journal 'The Builder' by your association... We would like to invite Mr DU Yangeng warmly to attend the Fourth International Congress of Building Societies held in Salzburg, Austria." Details of the conference were published in March 1934.

\subsection{Native construction}

The Builder has made a lot of coverage of the practice in the 1930s in Shanghai. It is an important treasure for research on the architecture and construction at that time.

[Projects] From 1933 to 1935, the Illustration column covered a large number of significant construction. It was mainly focused on the public projects, municipal engineering and some high-rise apartments. A large number of photos of site constructions (Fig. 7) and their full set of drawings were published. The famous Park Hotel and Broadway Mansion have been detailed in several periodicals. Sometimes, the budget of proposed projects was announced for supervision as well.

[Translation of Building Regulations] Since the Building Regulation was promulgated by the concession, the Chinese builders have been long beset by the administrative document because of the language barrier. To help the builders understand the regulation comprehensively and timely, its translation was serialized three times since the first issue. As soon as $\mathrm{Mu}-$ nicipal Councils made edits, they were translated in the journal.

[Technologies and buildings materials] To introduce foreign technologies was not sufficient since they also had to be applied appropriately locally. A lot of space involved the favourable foreign building 
materials cement and concrete, such as the articles "The Influence of Depositing Cement under the Air", "Fundamental Requirements for good concrete". Especially, the unique technical inventions and typical experience of application in Shanghai were highly encouraged; see the article "7 Important Points of The Artisan Well" in May 1933 for example. The promotion of domestic materials was another primary mission of the journal. The production and sales of domestic cement, steel windows, paint, and steel were annually reported. In the 1930s, these building materials allowed locals to move away from their dependence on imports.

[Others] The journal was not limited to construction and technology; it also assumed a certain amount of communication and business work. In the "Architects' and Builders' Inquiry Bureau" column, questions on published articles or opinions from readers were answered and discussed. Legal knowledge was important for the builders when signing a contract in the concession. The "Construction and Court" column was specially opened to advice and support native builders on that matter.

In August 1937, the Battle of Shanghai broke out. The journal had to be suspended, and editor DU led all the staff to the front line.

\section{ZHENGJI CONSTRUCTION TUTORIAL SCHOOL}

In 1930, the Association registered the Zhengji Construction Tutorial School in the Shanghai Municipal Bureau of Education, aiming to train the highly skilled construction professionals. The literal meaning of "Zhengji" (正基) in Chinese is "correctly placed foundation". Mr TANG Jingxian and Mr DU Yangeng served as president and dean respectively. By 1934, the number of students increased to more than 100 , and the number of faculty members reached 14.

It was a six-year program, divided into junior and senior parts. The main courses of the primary part were Chinese, English, mathematics, physics, chemistry and other basic disciplines. The statistics (Haiqing 2004) showed that there were 1440 credit hours in junior stage. The courses in math accounted for 720 credit hours, including Complete Arithmetic, Elementary Algebra, Plan \& Solid Geometry, Plane Trigonometry \& Tables, and Analytic Geometry. English courses occupied 380 credit hours, about $26.4 \%$ of the total. The ability to speak fluent English was a necessary condition for the builders in Shanghai. The curriculum in senior stage concentrated on civil engineering, including Applied Mechanics, Strength of Materials, Engineering Drawing, Surveying, Building Construction, and Reinforced Concrete Construction (The Builder 1936, April).
Favouring quality over quantity, recruiting standards were very high. Students were mainly composed of junior workers from construction companies or draftsmen from design companies. The "Zhengji" lasted for a total of seven years. More than 50 participants formally graduated (Haiqing 2004). They played an important role in the Shanghai construction industry.
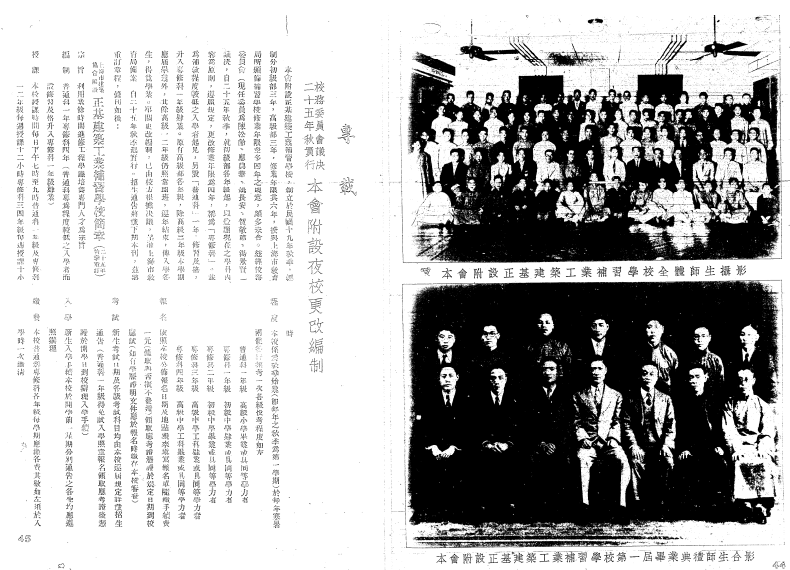

Figure 8. The reports on Zhengji Construction Tutorial School, The Builder, 1936.04, provided by Shanghai Library.

\section{CONCLUSION}

By focusing on the domestic agency and its publication, this paper has shown native builders' strong capacity of digestion, assimilation and diffusion of new western knowledge and technologies on industrialized construction techniques in a highly traditional context. Further, the local additions to otherwise acquired knowledge created a hybrid form of construction that would be further disseminated through the local context. Also, this paper highlights the construction technology transfer as a process of local desire to extract knowledge from numerous overseas sources, rather than a unidirectional colonial transfer. Thanks to the extensive exchange in the 1930s, some worldrenowned buildings could be realized in Shanghai.

\section{ACKNOWLEDGMENTS}

We would like to thank the Historical Archives of Shanghai Library, the Shanghai Local Chronicles, Shanghai Mingfu Library and the editorial department of Shanghai Pictorial for their help during the research. We are particularly grateful to $\mathrm{Mr}$. ZHAO Gangxiang for his endless assistance, input, and support. We would like to acknowledge the EPFL for the supporting this research and the $6 \mathrm{ICCH}$ for offering the chance to present the typical construction history of China. 


\section{REFERENCES}

Titles are freely translated from Chinese.

The Shanghai Builders' Association. A collection of the journal The Builder from 1932 to 1937. Historical Archives, Shanghai Library, Shanghai, China.

Shiling, Zheng. 2014. 中国近代建筑史料汇编(第一辑) The compilation of historical materials about Chinese modern Architecture. Shanghai: Tongii University Press.

Haiqing, Li. 2004. 中国建筑现代转型 The Modernization of Chinese Architecture. Nanjing: Southeast University Press.

Zhiquan, Jiang, ed. 2003. 千年回貽：上海建筑施工历史图集 Historical Album of the building construction in Shanghai. Shanghai: Shanghai Pictorial.

Wenda, Wu, ed. 1997. 上海建筑施工志 The chronicles of the construction in Shanghai. Shanghai: Shanghai Academy of Social Sciences.

Poncellini, Luca and Csejdy Julia. 2013. László Hudec (Chinese version). Shanghai: Tongji University Press.121-156.

Jiang, Wu. 2008. 上海百年建筑史1840-1949 The History of Shanghai Architecture 1840-1949. Shanghai: Tongji University Press.

Kun, Wang. 2011. “民国时期上海华人营造业群体研究” “Research on the Shanghai builders in Republic of China". PhD diss., Shanghai Normal University.

Xiaohua, Li. 2011. “近代上海营造业的生存和成长”“The Survival and Growth of the Shanghai construction industry in the $19^{\text {th }}-20^{\text {th }}$ centuries." Shanghai City Development 2011 April: 69-73.

Chongjian, He. 1994. “杜彦耿的《建筑月刊》”“DU Yangeng and the journal The Builder." Architecture 1994(6):34-35.

\section{APPENDIX}

The following table references the contents of the main articles in the 46 issues of The Builder.

Reports on western architecture

Latest projects in the west:

1932.12 The twenty-six story building of AT\&T in America

1933.06 Diversion Tunnels at Hoover Dam

1933.10 Modern Cinema Planning (by Mr J R Leathert)

1934.01 Highway Construction in USA

$1934.05 *$ *arm Building in the USA

1934.06 * Bridge-Building Practices in the USSR

1934.06 * First All-welded Highway Bridge in England Recently completed

1934.06 * Concrete Cantilever Roof Shelter Grandstand

$1934.09 *$ * Sea-wall Construction of Fort Monroe in USA

1934.11 * A Trip to Japan

1935.01 * The Bridges in Germany

1936.07 Underground fortress in French

1936.10 Modern museum

Technologies, equipment and materials in the west:

1932.11 the method of pouring cement in USA

1933.04 * Manufactured of colored cement

1933.04 * Modern Kitchen Equipment

1933.03 Two inventions: Cement pump, electromagnetic motor for pouring concrete

1933.06 The invention of Flush Toilet

$1933.09 *$ The Use of X-rays in architecture

1933.09 * Cold Applied Bitumen

1935.01 Concrete septic tank

\begin{tabular}{|c|c|}
\hline 1936.04 & Quick-Setting Cement \\
\hline 1936.08 & The steel applied in Park Hotel \\
\hline 1936.10 & Long tube light bulb \\
\hline 1936.10 & * Steel "Krupp Isteg" \\
\hline 1936.12 & Modern Bathroom \\
\hline 1937.04 & New electric crane \\
\hline \multicolumn{2}{|c|}{ Civil engineering: } \\
\hline 1934.01 & $\begin{array}{l}\text { * Hardy Cross Methods of Moment Distribution } \\
\text { (by LIN) }\end{array}$ \\
\hline 1934.02 & $\begin{array}{l}\text { * Calculating the C,K,F Properties of a Member } \\
\text { (by LIN) }\end{array}$ \\
\hline 1934.03 & $\begin{array}{l}\text { * Indirect Applications of the Cross' Method (by } \\
\text { LIN) }\end{array}$ \\
\hline 1934.05 & * Rigid Frame Concrete Bridge (by LIN) \\
\hline 1934.06 & $\begin{array}{l}\text { * Secondary Stress Analyzed by the Cross' } \\
\text { Method (by LIN) }\end{array}$ \\
\hline 1934.07 & $\begin{array}{l}\text { * Multi-story Frame Analyzed by the Cross' } \\
\text { Method (by LIN) }\end{array}$ \\
\hline 1934.09 & $\begin{array}{l}\text { * An "Exact" Moment Distribution Methods of } \\
\text { Continuous Frame Analysis (by LIN) } \\
\text { * Some Fundamental Laws in Advanced struc- }\end{array}$ \\
\hline $\begin{array}{l}1934.11 \\
+12\end{array}$ & $\begin{array}{l}\text { * Some Fundamental Laws in Advanced struc- } \\
\text { tural Theory (by LIN) }\end{array}$ \\
\hline 1935.01 & $\begin{array}{l}* \text { Hardy Cross Methods of Moment Distribution } \\
\text { and Calculating the C, K,F Properties of a Mem- } \\
\text { ber }\end{array}$ \\
\hline 1935.02 & $\begin{array}{l}\text { * Distribution and Load Factor for Arches (by } \\
\text { LIN) }\end{array}$ \\
\hline 1935.09 & Analysis of Miscellaneous Frames (by LIN) \\
\hline 1936.01 & The construction of modern bridges (by LIN) \\
\hline 1936.11 & $\begin{array}{l}\text { The provision of live loads of the major cities in } \\
\text { the USA. }\end{array}$ \\
\hline \multicolumn{2}{|c|}{ Latest developments in the west: } \\
\hline 1934.05 & $\begin{array}{l}\text { * Fourth International Congress of Building Soci- } \\
\text { eties }\end{array}$ \\
\hline 1934.05 & * Building Employment in America \\
\hline 1934.07 & * National Housing Act of USA \\
\hline 1935.02 & $\begin{array}{l}\text { 50th Anniversary of the Illinois Institute of Engi- } \\
\text { neers }\end{array}$ \\
\hline 1935.06 & The History of RIBA \\
\hline 1936.08 & The education of architects in the USA \\
\hline 1936.11 & $\begin{array}{l}\text { The preview of Architecture Expo in New York, } \\
\text { America }\end{array}$ \\
\hline 1937.04 & Paris Expo \\
\hline
\end{tabular}

Reports on native architecture

Illustrations:

\begin{tabular}{l|l}
$1932.12,1933.01 / 02 / 03$ & * Park Hotel \\
\hline $1933.05 / 06$ & * Shanghai Power Co. \\
\hline $1933.07+08$ & * Shanghai Race Club \\
\hline $1933.07+08,1935.03$ & * Picardie Apartment \\
\hline 1934.01 & * Hamilton House \\
\hline $1934.01,1934.03,1935.02$ & * Broadway Mansion \\
\hline 1934.08 & * "Times Square" Shanghai \\
\hline $1935.04,1935.06$ & * The Sun Co. \\
\hline 1935.08 & * Dauphine Apartment
\end{tabular}

Domestic Materials:

1932.12, 1933.02, $\quad$ Cement Industry of China

1934.11+12, 1936.01/09,

1933.01

1933.03

1935.01

1936.03

Steel frame Industry of SH

The sales of domestic paint

Steel Industry of China

Real Estate of Shanghai

* The content was originally in English when published. 